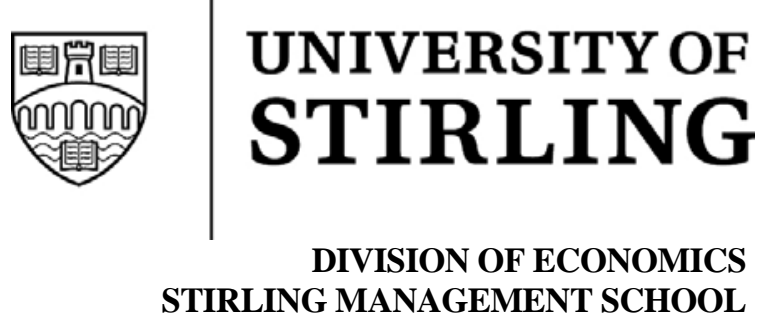

\title{
Workers Made Idle by Company Strikes and the 'British Disease'
}

Robert A. Hart

Stirling Economics Discussion Paper 2009-14

June 2009

Online at http://www.economics.stir.ac.uk 


\title{
Workers Made Idle by Company Strikes and the 'British Disease'
}

\author{
by \\ Robert A. Hart \\ Department of Economics \\ University of Stirling and IZA \\ r.a.hart@stir.ac.uk
}

June, 2009

\begin{abstract}
The strikes' literature is dominated by the causes and effects of strike action as they relate directly to strikers themselves. This paper considers another important group of affected workers - those individuals incidentally made idle as a result of the strike action of others. Using a unique data set of the British Engineering Employers' Federation (EEF), it examines the years 1960 to 1970, a critical period in Britain's postwar strikes' history. The mid-point of this decade marked the start of the era of the 'British Disease', a universally adopted title given to Britain's perceived international leadership in strikes incidence and industrial unrest. Workers made idle were an important symptom of the disease. In the study here, they accounted for $72 \%$ of days lost in disputes in which they were involved and $44 \%$ of total days lost in all disputes. Consideration is given to the likely causes of these incidental layoffs within 7130 strikes of EEF federated firms covering engineering, automotive and metal industries. Particular attention is given to the British car industry, accounting for $22 \%$ of total EEF strikes during the period of study. The regression analysis examines the causes of workers being made idle with explanatory variables covering labour market conditions, strikes durations, pay issues, non-pay issues. The regressions also control for company, union, geographical districts, annual and seasonal fixed effects.
\end{abstract}

Key Words: Strikes, workers made idle, pay disputes, non-pay disputes

JEL Classification: J52, L61, L62

Acknowledgements: Research was funded by ESRC Grant RES-000-22-1804. I am grateful to the Engineering Employers Federation for allowing access to their payroll statistics. I am also grateful to Warwick University Modern Record Centre and to the Glasgow University Archive Centre for their considerable help in assembling the material. This work has greatly benefited from the inputs of Andrew Currall and Daniel Currall who transcribed the data and from Elizabeth Roberts who provided excellent research assistance. 


\section{Introduction}

The nadir of post-war British industrial relations was reached in the 1970s/early

1980s. The related events were popularly referred to throughout the industrial world as the 'British Disease'. While this term referred to strikes and industrial unrest ${ }^{1}$, it was more generally associated with a decline of British manufacturing industry. This ranged from falling international competitiveness through to the weakness and eventual collapse of some large-scale companies. Prominent among the latter was the effective elimination of the British motor car industry. In fact, the year 1964 marked the start of the era of extreme industrial relations turbulence in Britain. Over the period of Harold Wilson's labour government of 1964 to 1970 , there was exceptional growth in strike incidence. The associated working days lost were, apart from the short event of the General Strike in 1926, unmatched over the previous 50 years.

Using a unique data set that was originally compiled by the Engineering Employers' Federation $(\mathrm{EEF})^{2}$, this paper concentrates on a highly significant group of

\footnotetext{
${ }^{1}$ British Disease: the pattern of strikes and industrial unrest in the 1970s and early 1980 s supposed by many during this time to be endemic in Britain and to weaken the British economy. (English Collins Dictionary)

${ }^{2}$ The EEF is the largest employers' organisation in the United Kingdom with a current membership of nearly 6000 companies throughout the country. It was established in 1896 and by 1899 had become known as the Engineering Employers' Federation. It later merged in 1918 with the National Employers' Federation and become known as the Engineering and Allied Employers' National Federation. In 1961 it changed its name back to the Engineering Employers' Federation. It covers mainly engineering, metal working, and automotive companies. The company membership averaged about 4500 over the period studied here (see Wigham, 1973, Appendix J). It accounted for between $30 \%$ and $35 \%$ of total engineering industry employment. One of the remarkable features of this organisation is that it compiled, on a thoroughly systematic basis, a complete strikes record for its member companies from 1920 to 1970 (Devereux and Hart, 2008). The data have recently been transcribed on to spreadsheets in a systematic fashion. They are available at the UK Data Archive: "An Evaluation of UK Engineering Strikes between 1920 and 1970”, SN 5841.
} 
workers who symbolise one of the most damaging aspects of the British Disease. These are non-striking workers who were incidentally laid off as the result of the strike action of others. They are referred to in what follows as workers made idle. Days lost due to workers made idle account for $44 \%$ of total days lost in the 7130 EEF member strikes between 1960 and 1970. If we confine attention only to company disputes in which workers were made idle, then this group account for $72 \%$ of total days lost.

The total number of days lost due to strike action within a given company derives from three categories of workers. First, days lost by strikers themselves. Second, days lost by workers in the company who are not directly involved in strike action but who are consequentially made idle. Third, days lost due to stoppages and disruptions in other branches of the affected company as well as other outside companies due to business and trading connectedness. ${ }^{3}$ The existing strikes literature has been overwhelmingly concerned with the first category of affected worker. Unsurprisingly, there is little micro evidence on the third loss of working time because of the associated complexity of data requirements. But even information on those within-company workers who are made idle by the strike action of others is difficult to obtain. The EEF strikes data offer insights into this aspect of the consequences of strike activity.

Attention is concentrated on the 11 year period from 1960 to 1970 for three main reasons (see also Devereux and Hart, 2008). First, as underlined in Figure 1, the second

\footnotetext{
${ }^{3}$ Turner, Clack and Roberts (1967, p54/55) give an example involving days lost through a combination of all three influences. It involved a 1960s British Motor Corporation (BMC) dispute in which a strike by less than 200 hoist operators led to a work stoppage of 6,000 other workers in the same plant and then to 8,000 operatives in other BMC plants being laid off. Such a dispute may well have caused days lost in outside supply firms, information on which would have been very difficult to obtain.
} 
half of this decade covers a period of historically high strikes incidence in engineering, car manufacture and other manufacturing industries. ${ }^{4}$ They mark the beginning of an era of strong union militancy within important sectors of British manufacturing. Second, statistics for this period can be broken down into 54 engineering districts - mostly defining EEF travel-to-work areas - for which matching monthly unemployment rates are available. Thirdly and partly related to the foregoing, the data allow us to control comprehensively for company, union, geographical district and time fixed effects all of which have a strong bearing on the incidence of workers made idle.

The paper is structured as follows. The discussion in Section 2 suggests likely factors that result in workers being made idle due to the strike actions by others. Section 3 describes the EEF data. The incidence of workers made idle within total strikes activity is featured in Section 4. Associated estimation and results are contained in Section 5. Section 6 concludes.

\section{Workers made idle due to the strike action of others.}

In this section, I outline a number of likely explanations of why company strike activity may force non-participants to cease working. I also indicate how the EEF strikes data help us to account or control for each of the eventualities.

\footnotetext{
${ }^{4}$ Figure 1 shows the incidence of strikes within EEF member companies over the period 1920 to 1970 . The late 1950s/early 1960s mark the start of an upturn in incidence which accelerated in 1965 and which by the late-1960s far exceed the incidence in the previous 40 years. The shape of the plot in Figure 1 is strongly indicative of British strikes' activity over this period. It holds for numbers of strikes in EEF companies and numbers of strikes in all industries (see Hart and Devereux, 2008, Figures 2a and 2b). See also the evidence presented in Silver (1977).
} 


\section{(a) Production constraints and job task interdependence}

Table 1 lists the categories of pay and non-pay disputes recorded in the EEF data and categorised in the UK Date Archive. The non-pay item, Production Constraints, concerns disputes involving interrupted work flow. Examples include 'under-manning', 'absenteeism causing extra work', 'alteration in the work sequence', 'problems with the work schedule', 'disruption due to line breakdowns' and 'poor work flow from other work groups'. In work environments with highly interrelated production and job task sequences, where individual value added is highly dependent on outputs of others, disruptions may spread to work groups who are not directly involved in an initial localised dispute. Line production is obviously vulnerable to such knock-on effects. The most prominent example of line production is car assembly. ${ }^{5}$ Work disputes in a given segment of the line may well entail both downstream and upstream repercussions. Downstream sections will suffer from a disrupted production flow. Upstream activity will be slowed down as bottlenecks accumulate. Clearly, in these situations, the work patterns of individuals not immediately involved in strike action can be adversely affected. In fact, the leverage effects of relatively small groups of strikers impacting on non-striking work colleagues can be quite substantial.

The EEF data allow for a stringent test of the effects of production constraints on workers made idle relative to other non-pay disputes. Thus, as well as incorporating a

\footnotetext{
${ }^{5}$ Of the 189 disputes in the EEF data under the heading Production Constraints, $48 \%$ occurred within the British car industry.The British car companies in the EEF data are Austin Motor Co Ltd, BMC Ltd, British Leyland, Morris Motors Ltd., and Rolls Royce Ltd. In all details referring to the car industry in what follows, I refer to these EEF member companies. Also, I ignore issues concerning mergers, takeovers and rationalisations within the British car industry during this period. I simply use the company names recorded by the EEF in its strikes' records.
} 
binary variable denoting this type of dispute, I can simultaneously account for individual company fixed effects which capture a broad set of production and organisational configurations.

\section{(b) Demarcation disputes}

The previous example involves disputes in which a given section of striking workers can make non-strikers idle because of production and organisational interdependence across company workers. However, the possibility of a dispute arising in one section of a company having wider impacts on workers elsewhere is not restricted only to the issues raised above. The non-pay category Job Demarcation in Table 1 provides an additional possibility. Demarcation disputes refer to disagreements between different unions representing workers in the company, or between workers in the same union, over the allocation of work across different categories of workers. So, for example, a demarcation dispute may involve objections - often via a representative union - by one category of worker to the employment of other categories of workers on given job tasks because they are alleged to lack the appropriate skills. ${ }^{6}$ A strike by workers who feel that they alone should undertake the work in question may lead to the disputed parties being made idle. ${ }^{7}$ Alternatively, and with the same possibility of outcome, an aggrieved

\footnotetext{
${ }^{6}$ Specific examples of such disputes in the EEF data include objections to (i) labourers being employed on plate moulding, (ii) the class of worker being employed on coreblowing machines, (iii) the employment of youths in certain job tasks, (iv) the employment of semiskilled labour on sandslinging machines, (v) the class of labour employed on metal pattern machining.

${ }^{7}$ In fact, such objections may arise while a group of workers are actually on strike. In the EEF data, for example, there is a case of a dispute involving the claim that non-testers handled work while testers were on strike.
} 
category of workers may take strike action because they consider that they are being required to perform job tasks that should be undertaken by work colleagues working under different job descriptions.

What was the potential for inter-union demarcation disputes within EEF companies? Table 2 shows the frequency distributions of numbers of unions operating in EEF member companies in which strikes occurred over the period. Within all companies, about $33 \%$ of striking companies experienced 2 or more unions representing their workforces. In car companies, this latter figure was almost double at $63 \%$. There were 385 incidents involving demarcation issues of which $17 \%$ involved car companies.

\section{(c) Strikes’ durations.}

We might expect that the incidence of workers made idle will correlate with strike durations. It is not clear, a priori, whether correlation will be negative or positive. Why might we find a negative association? First, strikers may attempt to spread the scope of the dispute, including deliberately making non-strikers idle, in order to increase the strike's economic impact on the company. This may have the result of weakening management's resolve to resist strike demands. Second, those workers who are made idle, for whatever reason, may exert pressure on strikers to reach a settlement of the dispute because of loss of income. Why might we find a positive association? Where strikes become protracted, workers may eventually be made idle as the lack of work flow from strikers increasingly limits the ability of non-strikers to execute job tasks. If maintenance workers go on strike, prolonged failure to deal with machine breakdowns will eventually seriously disrupt the work activity of machinists. If workers responsible for intermediate production and/or partly finished goods and/or replacement parts go on 
strike then this will eventually freeze the work activities of those whose jobs depend on the related supplies.

While the EEF data record the timing of the start of each strike as well as strike duration in days, there is clearly an endogeneity issue with this variable. Some of the foregoing arguments can be cast in terms of duration causing workers to be made idle or in terms of workers made idle affecting duration outcomes. The duration variable needs to be instrumented. The method of instrumentation is discussed in Section 5.

\section{(d) The timing of strikes}

In general terms, it is important to check whether trend and seasonal factors relate to strike activity, including workers made idle. Annual and monthly dummy variables are included to 'control' for these influences. But are there potential cyclical influences? Based on the EEF strikes data, Hart and Devereux (2008) find that successful strike outcomes, from the viewpoint of engineering unions and workers, are pro-cyclical. It might be expected that favourable outcomes are more likely to be achieved near to the peak of a cycle when company order books are full. The risks attached to taking strike action may increase towards cyclical troughs as outside labour market options for potential strikers become relatively scarce. Also, companies may be less likely to respond if, in any event, order books are thin and spare production capacity is high. If some unions attempt to press home advantages by strategically widening disputes to nonstriking company workers in order to increase related costs to the employer then cyclical impacts may also positively relate to the incidences of workers made idle.

The EEF data allow us to measure relative demand pressures - both across engineering geographical districts and through time - through the availability of detailed 
district-level unemployment rates. At the same time, union fixed effects allow us to control for relative union militancy.

\section{(e) Militancy}

Some unions, industries and geographical districts are linked with strike militancy. This may relate variously to such factors as political affiliation, social infrastructure, workplace conditions, management attitudes, and local workforce tradition. Militancy is likely to relate to the incidence of workers made idle. For example, militant union leadership in a given company dispute may seek to achieve widespread worker solidarity.

Militancy may manifest itself through the frequency of strike action in particular geographical areas. Here the British car industry has a particularly notable record during our study period (see Table 4). Where high and persistent strike frequencies occur, radical strike behaviour may be common among local working communities and may include pressurizing non-striking workers into joining on-going disputes or perhaps initiating direct action to halt continued work activity by non-strikers. Such possibilities underline the need to incorporate company, union and district fixed effects in work of this type.

\section{Data}

As shown in Figure 2, EEF strikes are dominated by disputes involving bluecollar workers. ${ }^{8}$ The EEF coverage of each individual strike is comprehensive. Thus, we obtain the name of the company involved, the union(s) involved, the geographical

\footnotetext{
${ }^{8}$ These are referred to as 'manual' workers in the EEF data, with white-collar workers classified as 'staff'.
} 
engineering district (e.g. Coventry) ${ }^{9}$, the cause of the strike, the outcome or resolution, the strike duration in days ${ }^{10}$ (with precise start and end dates), the numbers involved (by men, women and boys), the classes of workers involved (e.g. toolroom fitters, machinemen), whether or not the strike is in breach of procedures for avoiding disputes, and numbers of workers made idle as a result of the strike ${ }^{11}$. The causes of strikes are divided into pay and non-pay issues. There are no censored durations in the EEF strikes records because all reported strikes had ended at the end of the data.

From 1960 to 1970, the EEF averaged 4567 member companies. Of these, 863 were involved in at least one pay dispute and 762 were involved in at least one non-pay dispute. In total, there were 3671 pay disputes and 3459 non-pay disputes. Table 3 summarises per-company frequency distributions of pay and non-pay disputes. Clearly, the great majority of companies affected by strikes experienced less than 11 disputes over the period whereas on the right-tail of the distribution 16 companies were involved in more than 50 disputes over pay or non-pay issues. The latter are listed in Table 4. Assembly and supply companies in the British car industry account for $100 \%$ of these high-frequency non-pay disputes and $70 \%$ of the high frequency pay-related disputes. This domination is even more remarkable given that the vast majority of car strikes occurred in the second half of the period. This is shown in Figure 3 which graphs strike

\footnotetext{
${ }^{9}$ Matching district-level unemployment rates are available in the electronic data base.

${ }^{10}$ For strikes lasting less than a day, durations are reported in hours.

${ }^{11}$ If a strike lasts for $x$ days, the EEF records the number of strikers and the number of workers made idle as experiencing the same $x$-day durations. This is unlikely to be true in all cases. Some strikes are likely to involve workers being made idle at later stages; for example, the supply of intermediate goods and services may take time to dry up. It may well be the case, therefore, that the numbers of reported working days lost due to non-direct layoffs may exceed actual layoffs.
} 
incidence. There is a clear 'take-off' in strike activity from 1964 throughout EEF member companies. Among car companies, the incidence rose from under $5 \%$ of total strikes in the early 1960 s to $30 \%$ by the end of the period.

Summaries of the main issues involved in pay and non-pay strikes are shown in Table 1 together with their relative frequency over the 1960 to 1970 period. ${ }^{12}$ The percentage share of non-pay to total disputes year by year, as shown in Figure 4, is relatively stable over the period, at roughly $50 \%$ of all disputes. In the car industry by contrast non-pay disputes account for about 70\% of all disputes during the key $1965-$ 1970 period.

In the following, I differentiate between the 7130 total recorded strikes and the 1641 recorded car strikes.

\section{The relative importance of workers made idle within total days lost due to strikes}

For the years 1960 to 1970 , let $T D L_{t}$ be the total days lost in all EEF strikes in year $t$. The total can be decomposed into number of strikes, average number of workers laid off by strikes, and the average strike duration (Forchheimer, 1948 and Knowles 1952). Thus, we have

(1) $\ln \left(T D L_{t}\right)=\ln \left(S_{T t}\right)+\ln \left(\bar{N}_{T t}\right)+\ln \left(\bar{D}_{T t}\right)$

where $S_{T t}=$ total number of strikes in year $t, \bar{N}_{T t}=$ average number of workers laid off per strike (i.e. strikers and workers made idle), $\bar{D}_{T t}=$ average duration of strikes.

\footnotetext{
${ }^{12}$ Brief specific details of pay or non-pay issues for each individual strike are available in the strikes' database.
} 
Similarly, let $M D L_{t}$ be the total days lost in year $t$ due to workers made idle. Then we have

$$
\ln \left(M D L_{t}\right)=\ln \left(S_{M t}\right)+\ln \left(\bar{M}_{M t}\right)+\ln \left(\bar{D}_{M t}\right)
$$

where $S_{M t}=$ total number of strikes in year $\mathrm{t}$ that include workers made idle, $\bar{M}_{M t}=$ average number of workers made idle in $S_{M t}, \bar{D}_{M t}=$ average duration of strikes involving workers made idle.

Figure 5 graphs the contributory shares in expression (1) while Figure 6 shows the equivalent outcomes in respect of expression (2). Comparing these Figures, the major differences are (a) the number of strikes is the major contributory factor to total days lost in Figure 5 and (b) the average numbers of workers made idle contribute most to total days lost in Figure 6. This underlines the fact that workers made idle comprise significant proportions of total days lost within strikes in which they occur. The average duration of strikes are roughly comparable in both figures, as can be checked by consulting Table 5 which breaks strikes durations into all disputes as well as pay and nonpay disputes. Note, however, that the size of strikes - measured in terms of total workers laid-off - are considerably larger if workers made idle are involved.

The percentage of total working days lost due to workers made idle is given by 100. $\exp \left[\ln \left(M D L_{t}\right)-\ln \left(T D L_{t}\right)\right]$ and presented in Figure 7 for all companies and for car companies separately. ${ }^{13}$ Days lost due to workers made idle accounted for an average of

\footnotetext{
${ }^{13}$ Car companies are omitted before 1965 because they accounted for relatively very few strikes (see Figure 3).
} 
$44 \%$ of total days lost in all companies between 1960 and $1970 .{ }^{14}$ In car companies between 1965 and 1970 workers made idle accounted for $68 \%$ of total days lost. The peak occurred in 1967 when $83 \%$ of total working days lost in British car manufacture were accounted for by workers made idle. In fact, $57 \%$ of total disputes in car plants between these dates involved workers made idle. But these percentages under represent the true impacts of workers made idle. Figure 8 confines attention to strikes that include workers made idle. Workers made idle average $72 \%$ of total days lost in such companies from 1960 to 1970. In every year from 1962 to 1967, workers made idle accounted for over $80 \%$ of total days lost in these companies. ${ }^{15}$ In the late 1960 s there was a decline from these extraordinarily high percentages culminating in 1970 when $57 \%$ of days lost in company strikes involving workers made idle were accounted for by such workers. In general, the overall leverage effects on total time lost due to workers made idle were clearly substantial.

\section{Regression specifications and findings}

I now make use of the complete data to test for the main factors that affect the probability of strikes including workers made idle. In particular, I test directly for the influences that are suggested in Section 2, while controlling for company, union, district and time (annual and monthly) fixed effects. These are clearly a highly detailed and wide-ranging set of controls and so tests of the significance of individual issues are especially stringent.

\footnotetext{
${ }^{14}$ The annual average of total days lost is 1.1 million days, with a trough of 0.6 million days in 1961 and a peak of 2.2 million days in 1970.

${ }^{15}$ Given the extremely high incidence of workers made idle in car company disputes between 1965 and 1970, the car graph in Figure 8 differs little from that in Figure 7.
} 
First, consider pay-related strikes, with the pay issues listed in Table 3. Let $M P=$ 1 if a given pay-related strike involves workers made idle and $M P=0$ if only direct strikers are involved. Then, using a simple linear probability specification ${ }^{16}$, and in terms of strike $i$ in engineering district $d$ at time $t$, the regression equation takes the form

(3) $M P_{i d t}=\alpha_{0}+\alpha_{1} \hat{D}_{i d t}+\alpha_{2} U_{d t}+\alpha_{3}\left(\right.$ Pay Issues $\left._{i d t}\right)+\alpha_{4}($ Company Dummies $)$

$$
\begin{aligned}
& +\alpha_{5}(\text { Union Dummies })+\alpha_{6}(\text { District Dummies })+\alpha_{7}(\text { Year Dummies }) \\
& +\alpha_{8}(\text { Month Dummies })+\varepsilon_{i d t}
\end{aligned}
$$

where $\hat{D}$ is instrumented strike duration, $U$ is a district level unemployment rate $^{17}$ and $\varepsilon$ is an error term.

Second, consider non-pay-related strikes, again itemised in Table 3. Let $M N=1$ if a given non-pay-related strike involves workers made idle and $M N=0$ if only direct strikers are involved. Then the equivalent to (3) for this class of strikes is given by

(4) $M N_{i d t}=\beta_{0}+\beta_{1} \hat{D}_{i d t}+\beta_{2} U_{d t}+\beta_{3}\left(\right.$ Non - Pay Issues $\left._{i d t}\right)+\beta_{4}($ Company Dummies $)$

$$
\left.\left.\left.+\beta_{5} \text { (Union Dummies }\right)+\beta_{6} \text { (District Dummies }\right)+\beta_{7} \text { (Year Dummies }\right)
$$$$
+\beta_{8} \text { (Month Dummies) }+\varepsilon_{\text {idt }}
$$

How is the durations' variable instrumented? It turns out that the EEF data contain two strong instrumental variables. The EEF had a laid down procedure for dealing with disputes arising in the workplace. There was a somewhat convoluted

\footnotetext{
${ }^{16}$ The choice is conditioned by the fact that the regressions control for company, union, district and time fixed effects and so fixed effects probits may be biased due to the incidental parameters problem (Greene, 2003).

${ }^{17}$ Given that more than one strike may occur in district $r$ at time $t$, I cluster the standard errors in equations (3) and (4) at the year/month/district level in these regressions. I have verified that the analogous 2 -step approach (e.g. Devereux, 2001) gives very similar estimates of coefficients and standard errors.
} 
grievance formula under the so-called 'provisions for avoiding disputes'. ${ }^{18}$ Turner, Clack and Roberts (1967), work out that in 1964/5 the average time between submitting a dispute to formal procedure and its final outcome - which may have ended-up with a failure by the parties to agree - averaged over 7 weeks in engineering cases and over 13 weeks in car manufacturing cases. Exceptionally difficult cases could take over 6 months. Unsurprisingly, unions often favoured direct 'unofficial' negotiation with plant managers rather than risk a lengthy process that may eventually involve outside adjudicators.

The EEF systematically recorded whether a given strike followed or was in breach of the laid-down provisions for avoiding disputes and reported outcomes separately for blue collar and white collar workers. The contention here is that these variables are strong instruments for strikes durations. It is likely that unions and workers were most likely to incur the time costs associated with following procedure if and only if they felt that a given dispute involved complex issues that were unlikely easily to be resolved at plant level. By contrast if the details surrounding a dispute appeared a priori to be relatively simple and straightforward then it was probably deemed to be worthwhile to breach procedure and attempt to sort matters with local management. Figure 9 reveals that this latter course of action was the one pursued by the large majorities of both blueand white-collar workers. Of course, the strategies of following or ignoring laid-down procedure could and did break down, resulting in strike activity. If 'going through procedure' signaled less tractable disputes then subsequent strikes would be expected to be longer than those in which procedure had been ignored because they were deemed

${ }^{18}$ Depending on its degree of tractability, a given dispute could initially involve work floor foremen and then higher-level managers within the company and then proceed outside the company to relevant local unions and local employers associations and then, if necessary, to national union and representative employer levels. 
simple enough to be solved at workshop level. In fact, this outcome is confirmed in Table 6 which shows clearly that strikes occurring after laid-down procedure had taken place lasted considerably longer than strikes that breached procedure.

In summary, whether or not procedure was followed among blue- and whitecollar workers in the period preceding a given strike offers a strong instrument for the strike duration variable. In the first place, it is positively associated with the duration of the subsequent strikes. Secondly, given that it involves procedural issues of negotiations that may or may not subsequently lead to strike actions, it seems highly reasonable to assume that it is will be independent of the error term in equation (3) or (4).

Results to equation (3), covering pay disputes, are presented in Table 7. Workers made idle are significantly positively related to strikes' durations. However, the magnitude is small: a one day increase in duration is associated with an increased probability of workers made idle by just 0.007 . District unemployment rates have no statistical effect. This would seem to rule out opportunistic behaviour on the part of strikers that is linked to the tightness of the labour market and that seeks to widen strike action to add pressure on employers. In contrast, Devereux and Hart (2008) find, over the same time period, that strike resolutions are more favourable to unions when the unemployment rate is low. Disputes over Piece Rates, affecting almost 13\% of all pay disputes, is the excluded dummy in respect of pay issues. Only disputes over Bonuses and over Miscellaneous pay issues (see Table 1) display significant impacts on the probability of being made idle. Both have positive influences.

So, Table 7 provides limited evidence that pay-related issues impacted on the probability of strikes including workers made idle. One problem is that wage disputes 
account for, unsurprisingly, over half of all pay-related disputes and so it is difficult to discern - in the absence of much greater detail of the specifics of remuneration grievances - which aspects of pay are most likely to result in workers being made idle. By contrast, we see from Table 1 that there is no such predominant issue in respect of non-pay disputes. Also, there is a somewhat wider breakdown of total issues. This might serve to give more 'bite' to the non-pay effects on workers made idle. Moreover, as shown in Figure 10, while pay-related disputes within strikes in which workers were made idle predominated in the early years of our data, post-1963 there was a growth in the incidence of non-pay disputes culminating in a reversal of the relative importance of pay/non-pay disputes by 1965 . This trend was especially apparent in the British car industry. In fact, since the incidence of car strikes was low in the first-half of the period, it is clear that non-pay issues constituted easily the more important reason for strike action in this industry (see also Figure 4).

Results in respect of non-pay issues are shown in Table 8. As with pay disputes, the durations variable is significantly positive in the non-pay equation (4) but with almost twice the coefficient size. Unemployment continues to display no impact, however. The excluded non-pay issue is Treatment of Workers, accounting for $10 \%$ of non-pay disputes. After the comprehensive control of fixed effects, disputes covering three nonpay issues - Production Constraints, Job Demarcation and Redundancy - add significantly to the probability of workers being made idle. As discussed in Sections 2 (a) and 2(b) the first two types of strike issue involve the propensities of disputes to spread from an initial localised epicentre out to other work-sections of a company. The 
third, involving worker redundancies, is not so straightforwardly explained. ${ }^{19}$ Finally, and again relative to the Treatment of Workers, disputes concerning Working Time are significantly associated with workers made idle. There are 300 such disputes in the data and, once again, the car industry predominates, accounting for $45 \%$ of the total. This issue, however, is associated with a lower probability of the strike involving workers made idle.

\section{Conclusions}

Using a unique data set on strike activity within the EEF, this paper offers one of the first insights into the phenomenon of workers made idle by the strike actions of others. Member EEF companies represent core elements of British engineering, metal manufacturing and automotive industries and accounted for about one-third of total employment in these sectors. The analysis covers the period 1960 to 1970 , a decade that marked an escalation of British industrial relations problems that were to last into the early 1980s. Disruptions to production and associated production costs were greatly magnified in disputes that involved workers made idle. In fact, they accounted for between three and four times the working days lost of those directly involved in strike actions. Added to this, strikes involving workers made idle were relatively large scale (see Table 5).

${ }^{19}$ There are 571 demarcation-related strike incidents in the EEF data involving disputes over redundancy. Many of these involve workers protesting against the redundancy of others. Of course, such workers constitute bone fide strikers. However, unless there is absolute solidarity within the company's workforce, some workers will not want to join such a strike because they themselves are not directly affected by the issues at hand. However, to the extent that the strike action is undertaken widely in the company then those who do not wish to take part may be unavoidably made-idle due to severe input and output disruptions. 
The relative sizes of strikes involving workers made idle combined with the special 'grievance issues' among those affected served to make such strikes highly visible to the outside world and contributed to the popular notion of the British Disease. No industry typified the Disease more than British car manufacture, an industry that suffered a prolonged terminal illness. Car firms exhibited easily the highest frequencies of both pay and non-pay disputes (see Table 4) and were especially prone to disputes that embraced non-striking workers (see Figure 7). Literature on the plight of the British car industry in the 1960s and beyond is dominated by descriptions of industrial relations problems that embraced union militancy, the power of shop stewards, and poor management practices. Industrial relations issues almost certainly played a central role in the industry's eventual demise. But outcomes were exacerbated by an acute vulnerablity to widespread and costly disputes. The dominance of interrelated job tasks and systematised production sequences served to increase the risk that non-striking workers would be made idle. Further, $63 \%$ of striking car companies had 2 or more representative unions, twice the norm among all EEF member companies. The presence of several unions within the workplace was a catalyst for disputes involving demarcation issues. In fact $17 \%$ of demarcation strike incidents in our data involved car companies. Such disputes are found here to be significantly related to the probability of workers made idle. 


\section{$\underline{\text { References }}$}

Devereux, P J. 2001. The cyclicality of real wages within employer-employee matches. Industrial and Labor Relations Review, Vol. 54, July, pp. 835-850.

Devereux, P J and R A Hart. 2008. A good time to stay out? Strikes and the business cycle. Bonn: IZA Discussion Paper \# 3614.

Forchheimer, K. 1948. "Some international aspects of the strike movement." Bulletin of the Oxford Institute of Statistics 10, 9-24.

Greene, W. 2003. Fixed effects and bias due to the incidental parameters problem in the Tobit model. Department of Economics, Stern School of Business, New York University.

Knowles, K G J C. 1952. Strikes - a study in industrial conflict. Oxford, Basil Blackwell.

Silver, M. 1977. Recent British strike trends: a factual analysis. In E W Evans and S W Creigh (eds), Industrial Conflict in Britain. London: Frank Cass.

Turner, H A, G Clack and G Roberts. 1967. Labour relations in the motor industry. London: George Allen and Unwin.

Wigham, E. 1973. The power to manage. A history of the Engineering Employers' Federation. London: Macmillan. 

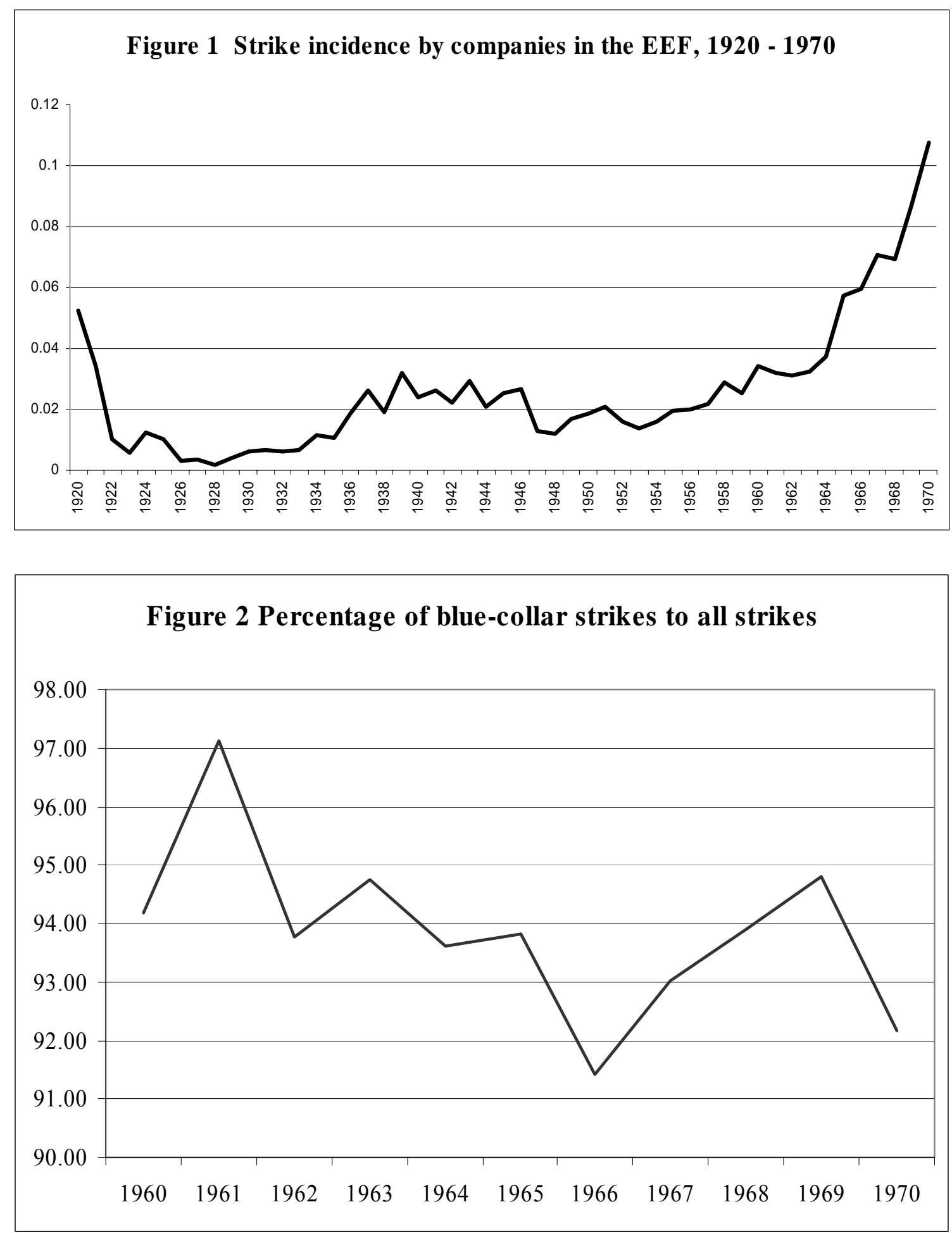

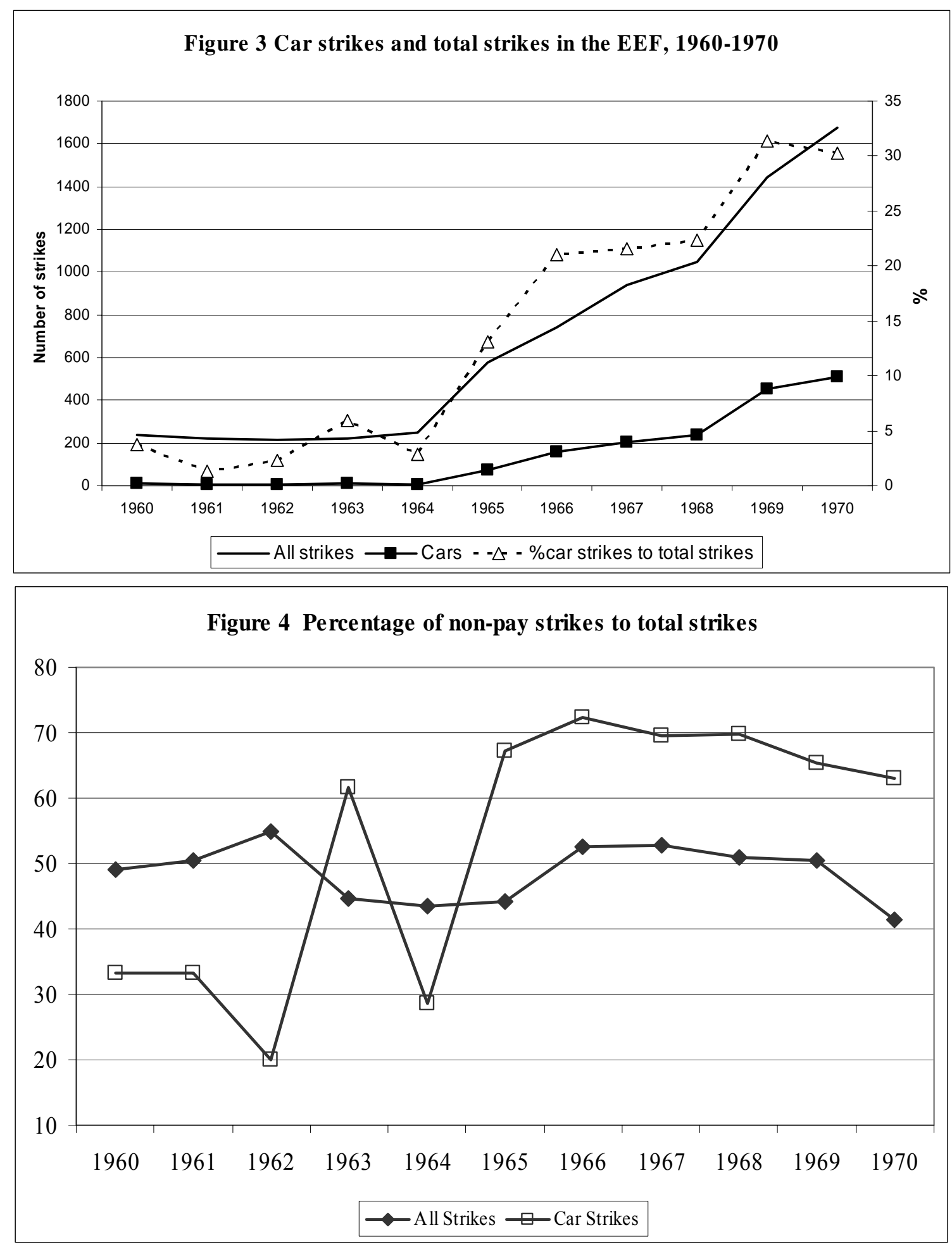

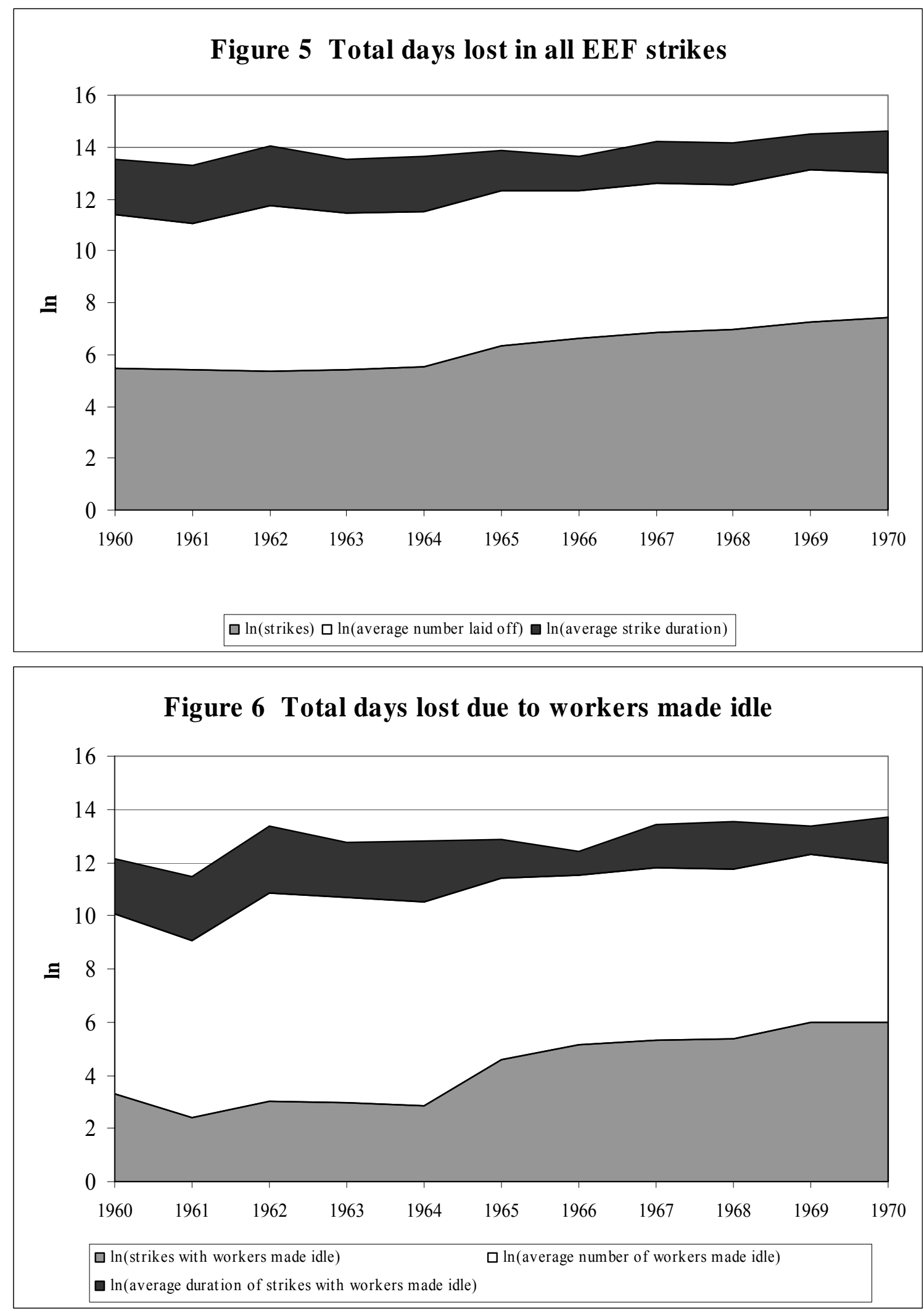

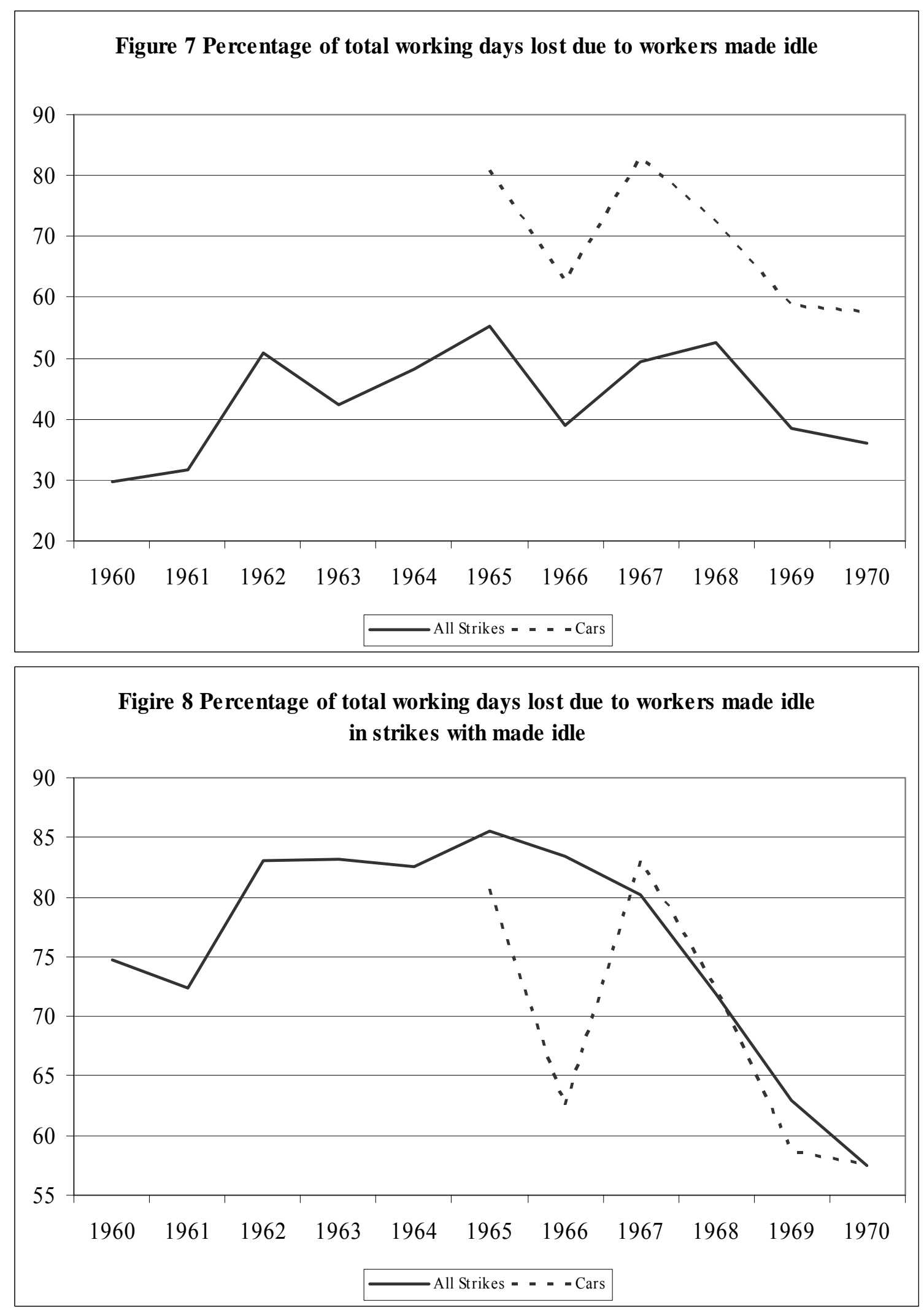


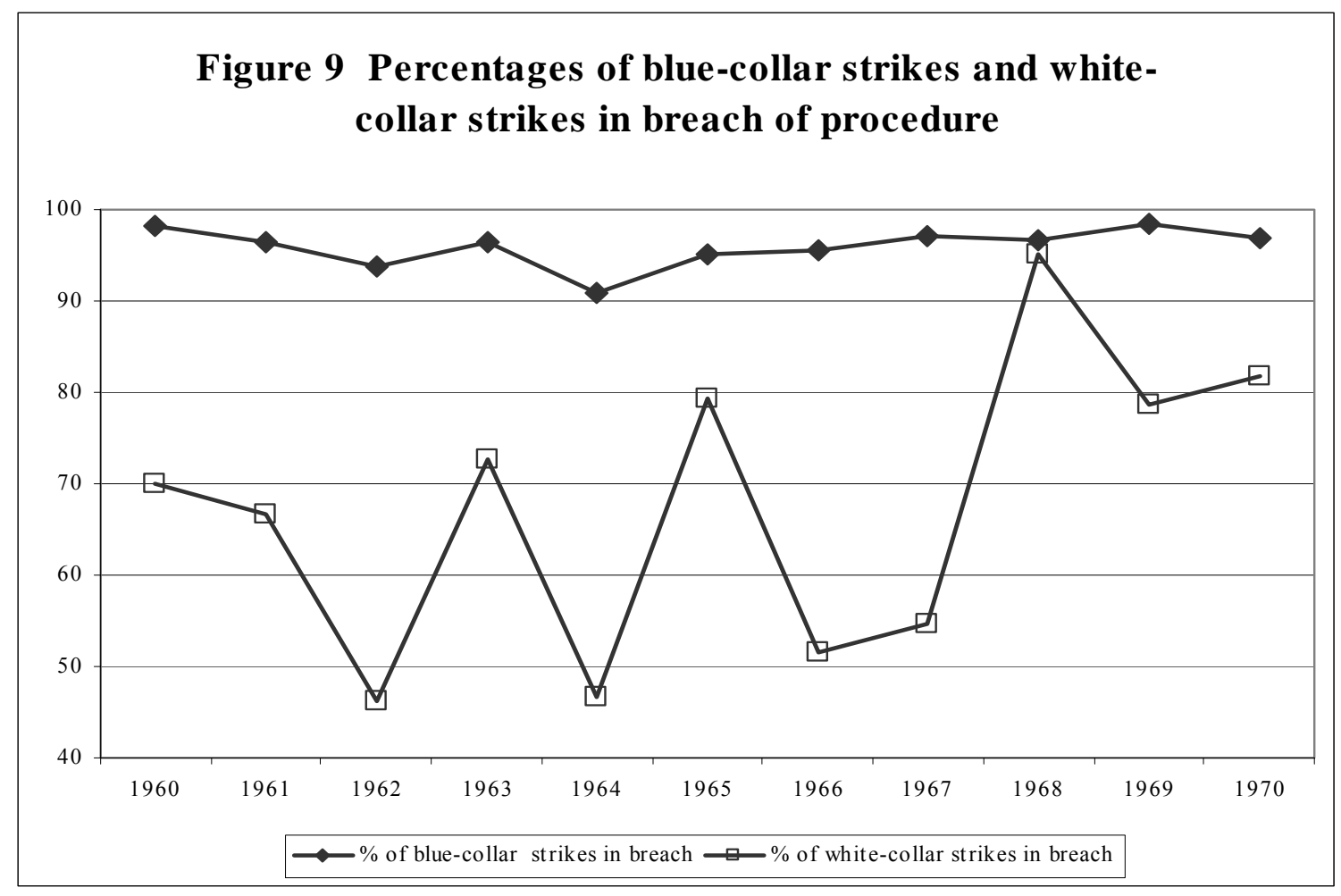

Figure 10 Percentage of non-pay strikes to total strikes involving workers made idle

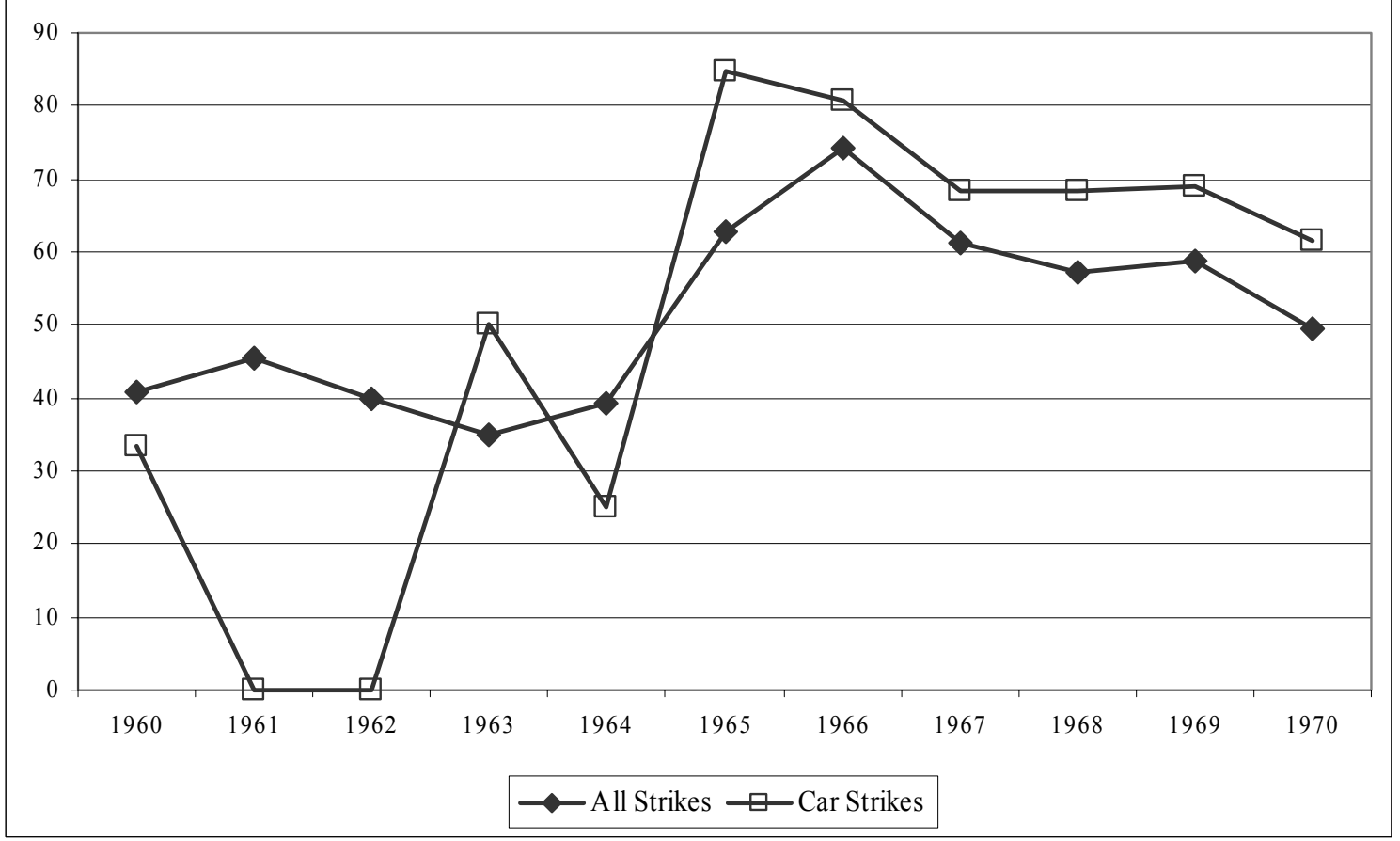


Table 1 Causes of Pay and Non-Pay in EEF Strikes, 1960 - 1970

\begin{tabular}{|c|c|c|c|}
\hline Pay Disputes & $\begin{array}{c}\text { Relative } \\
\text { frequency }\end{array}$ & Non-Pay Disputes & $\begin{array}{c}\text { Relative } \\
\text { Frequency }\end{array}$ \\
\hline Wages & 52.4 & Wrongful Dismissal & 12.3 \\
\hline Bonuses & 16.9 & Treatment of Workers & 10.2 \\
\hline Piece Rates & 12.9 & Union-Related & 7.5 \\
\hline Overtime & 0.1 & Redundancy & 4.0 \\
\hline Shift/Night Rates & 0.1 & Use of Outside Labour & 0.9 \\
\hline Relative Pay & 3.1 & Supervision/Management & 4.4 \\
\hline Systems of Pay & 5.0 & Systems of Working Time & 6.2 \\
\hline Holiday Pay & 2.1 & Apprentices & 0.1 \\
\hline Payment for Time Lost & 6.3 & Job Demarcation & 5.5 \\
\hline Holiday Time & 0.3 & Production Constraints & 4.6 \\
\hline \multirow[t]{7}{*}{ Miscellaneous } & 0.9 & Sympathy with Others & 3.3 \\
\hline & & Work Environment & 10.2 \\
\hline & & Working Hours & 7.6 \\
\hline & & Work Flexibility & 10.4 \\
\hline & & $\begin{array}{l}\text { Delay in/Refusal to Open } \\
\text { Negotiation }\end{array}$ & 4.4 \\
\hline & & Attendance at Union Meetings & 3.0 \\
\hline & & Miscellaneous & 5.8 \\
\hline
\end{tabular}


Table 2 Number of Unions Representing Workers in EEF Striking Companies, 1960-1970

\begin{tabular}{|l|c|c|}
\hline $\begin{array}{l}\text { Number of } \\
\text { Unions }\end{array}$ & $\begin{array}{c}\text { All Companies } \\
\text { \% Frequency }\end{array}$ & $\begin{array}{c}\text { Car Companies } \\
\text { \% Frequency }\end{array}$ \\
\hline $\mathbf{1}$ & 67.4 & 36.6 \\
$\mathbf{3}$ & 16.9 & 29.3 \\
$\mathbf{4}$ & 10.9 & 32.4 \\
$\mathbf{5 - 1 0}$ & 2.7 & 1.0 \\
\hline Total & 2.1 & 0.7 \\
\hline
\end{tabular}

Table 3 Frequency distributions of company pay and non-pay disputes, 1960 - 1970

\begin{tabular}{|l|c|c|}
\hline Disputes per Company & Pay Disputes & Non-Pay Disputes \\
\hline $\mathbf{1}-\mathbf{5}$ & 417 & 2615 \\
$\mathbf{6}-\mathbf{1 0}$ & 314 & 45 \\
$\mathbf{1 1}-\mathbf{2 0}$ & 71 & 24 \\
$\mathbf{2 1}-\mathbf{5 0}$ & 34 & 11 \\
$\mathbf{5 1}-\mathbf{1 0 0}$ & 17 & 1 \\
$>\mathbf{1 0 0}$ & 7 & 5 \\
\hline Number of Companies & 3 & 762 \\
\hline Total Frequency & 863 & 3459 \\
\hline Mean Frequency & 3671 & 4.5 \\
\hline
\end{tabular}


Table 4 Companies with over 50 pay and/or non-pay disputes, 1960-1970

\begin{tabular}{|c|c|c|c|}
\hline $\begin{array}{l}\text { Companies with a } \\
\text { frequency greater } \\
\text { than } 50\end{array}$ & $\begin{array}{c}\text { Pay Disputes } \\
\text { (Frequency) }\end{array}$ & $\begin{array}{l}\text { Companies with a } \\
\text { frequency greater } \\
\text { than } 50\end{array}$ & $\begin{array}{c}\text { Non-Pay } \\
\text { Disputes } \\
\text { (Frequency) }\end{array}$ \\
\hline $\begin{array}{l}\text { British Motor } \\
\text { Corporation Ltd. }\end{array}$ & 189 & $\begin{array}{l}\text { British Motor } \\
\text { Corporation Ltd. }\end{array}$ & 400 \\
\hline British Leyland & 158 & British Leyland & 320 \\
\hline $\begin{array}{l}\text { Pressed Steel Fisher } \\
\text { Ltd. }\end{array}$ & 107 & $\begin{array}{l}\text { Pressed Steel Fisher } \\
\text { Ltd. }\end{array}$ & 256 \\
\hline Joseph Lucas Ltd. & 82 & Morris Motors Ltd. & 157 \\
\hline $\begin{array}{l}\text { Hawker Siddeley } \\
\text { Ltd. }\end{array}$ & 58 & Austin Motor Co. Ltd. & 115 \\
\hline $\begin{array}{l}\text { Austin Motor Co. } \\
\text { Ltd. }\end{array}$ & 56 & Rolls Royce Ltd. & 51 \\
\hline Rolls Royce Ltd. & 55 & & \\
\hline Rover Co. Ltd. & 53 & & \\
\hline Plessey Co. Ltd. & 51 & & \\
\hline Smiths Industries & 51 & & \\
\hline
\end{tabular}


Table 5 Means and Medians of Strike Durations

\begin{tabular}{|c|c|c|c|c|c|c|c|c|c|c|c|c|}
\hline \multirow{4}{*}{$\begin{array}{l}\text { ALL COMPANIES } \\
\text { Duration }\end{array}$} & \multicolumn{4}{|c|}{ All Strikes } & \multicolumn{4}{|c|}{ Pay-related strikes } & \multicolumn{4}{|c|}{ Non-pay strikes } \\
\hline & \multicolumn{2}{|c|}{ All Strikes } & \multicolumn{2}{|c|}{ Strikes with Made Idle } & \multicolumn{2}{|c|}{ All Strikes } & \multicolumn{2}{|c|}{ Strikes with Made Idle } & \multicolumn{2}{|c|}{ All Strikes } & \multicolumn{2}{|c|}{ Strikes with Made Idle } \\
\hline & Mean & Median & Mean & Median & Mean & Median & Mean & Median & Mean & Median & Mean & Median \\
\hline & 7 & 2 & 7.25 & 1.5 & 9.2 & 2.25 & 11 & 3 & 4.8 & 1.5 & 4.4 & 1 \\
\hline Size & 352 & 89 & 820 & 330 & 325 & 70 & 942 & 325 & 379 & 106 & 726 & 332 \\
\hline $\begin{array}{l}\text { CAR COMPANIES } \\
\text { Duration }\end{array}$ & 2 & 0.75 & 1.5 & 0.5 & 3.1 & 1 & 2 & 0.8 & 1.4 & 0.5 & 1.2 & 0.5 \\
\hline Size & 614 & 204 & 846 & 343 & 791 & 194 & 1226 & 432 & 521 & 213 & 660 & 322 \\
\hline
\end{tabular}


Table 6 Average strike durations and strikes in breach/not-in-breach of procedure

\begin{tabular}{|c|c|c|c|c|}
\hline & $\begin{array}{c}\text { Blue-collar in } \\
\text { breach of } \\
\text { procedure }\end{array}$ & $\begin{array}{c}\text { Blue-collar not } \\
\text { in breach of } \\
\text { procedure }\end{array}$ & $\begin{array}{c}\text { White-collar in } \\
\text { breach of } \\
\text { procedure }\end{array}$ & $\begin{array}{c}\text { White-collar } \\
\text { not in breach } \\
\text { of procedure }\end{array}$ \\
\hline & \multicolumn{4}{|c|}{ Average Strike durations (days) } \\
\hline $\mathbf{1 9 6 0}$ & 8.0 & 15.0 & 14.6 & 58.7 \\
\cline { 2 - 5 } $\mathbf{1 9 6 1}$ & 7.8 & 25.4 & 27.5 & 95.0 \\
\cline { 2 - 5 } $\mathbf{1 9 6 2}$ & 8.3 & 19.1 & 16.7 & 41.0 \\
\hline $\mathbf{1 9 6 3}$ & 7.6 & 17.4 & 6.8 & 36.7 \\
\cline { 2 - 5 } $\mathbf{1 9 6 4}$ & 6.1 & 19.1 & 8.3 & 37.9 \\
$\mathbf{1 9 6 5}$ & 3.7 & 18.2 & 4.5 & 18.3 \\
\hline $\mathbf{1 9 6 6}$ & 2.7 & 6.4 & 5.9 & 23.9 \\
\hline $\mathbf{1 9 6 7}$ & 4.1 & 14.6 & 4.8 & 15.5 \\
\cline { 2 - 5 } $\mathbf{1 9 6 8}$ & 4.4 & 14.8 & 7.0 & 97.3 \\
\cline { 2 - 5 } $\mathbf{1 9 6 9}$ & 3.0 & 22.3 & 5.8 & 37.8 \\
$\mathbf{1 9 7 0}$ & 4.4 & 16.3 & 9.6 & 24.4 \\
\hline
\end{tabular}


Table 7 Results to Regression Equation (3)

\begin{tabular}{|c|c|}
\hline EXPLANATORY VARIABLES & ESTIMATED EFFECTS \\
\hline$\hat{D}$ & $0.007 *(0.003)$ \\
\hline $\boldsymbol{U}$ & $-0.007(0.016)$ \\
\hline Constant & $-0.148(0.175)$ \\
\hline PAY ISSUES § & \\
\hline Wages & $0.021(0.032)$ \\
\hline Bonuses & $0.085 *(0.036)$ \\
\hline Overtime & $-0.115(0.152)$ \\
\hline Shift/Night rates & $0.071(0.085)$ \\
\hline Relative Pay & $-0.008(0.050)$ \\
\hline Systems of Pay & $0.032(0.048)$ \\
\hline Holiday Pay & $-0.005(0.049)$ \\
\hline Payment for Time Lost & $0.038(0.047)$ \\
\hline Holiday Time & $0.111(0.125)$ \\
\hline Miscellaneous & $0.186 *(0.095)$ \\
\hline
\end{tabular}

Notes: There are 3669 observations. Regression includes dummies to control for union, district, company, year, and month fixed effects. Standard errors in brackets. * Denotes $5 \%$ significance. $\S$ Excluded pay issue is Piece Rates. 
Table 8 Results to Regression Equation (4)

\begin{tabular}{|c|c|}
\hline EXPLANATORY VARIABLES & ESTIMATED EFFECTS \\
\hline$\hat{D}$ & $0.013 *(0.005)$ \\
\hline$U$ & $-0.004(0.012)$ \\
\hline Constant & $-0.089(0.284)$ \\
\hline \multicolumn{2}{|l|}{ NON-PAY ISSUES § } \\
\hline Wrongful dismissal & $0.049(0.037)$ \\
\hline Union-related & $0.039(0.044)$ \\
\hline Redundancy & $0.090 *(0.046)$ \\
\hline Outside labour & $-0.003(0.082)$ \\
\hline Supervision/management & $0.012(0.052)$ \\
\hline Systems of supervision & $0.048(0.047)$ \\
\hline Apprentices & $0.127(0.077)$ \\
\hline Demarcation & $0.094 *(0.049)$ \\
\hline Production constraints & $0.109 *(0.047)$ \\
\hline Sympathy with others & $-0.039(0.059)$ \\
\hline Work environment & $0.086(0.046)$ \\
\hline Working hours & $-0.142 *(0.055)$ \\
\hline Work flexibility & $0.042((0.041)$ \\
\hline Problem with negotiation & $0.056(0.050)$ \\
\hline Attendance at union meetings & $-0.050(0.059)$ \\
\hline Miscellaneous & $0.078(0.051)$ \\
\hline
\end{tabular}

Notes: There are 3347 observations. Regression includes dummies to control for union, district, company, year, and month fixed effects. Standard errors in brackets. * Denotes $5 \%$ significance. § Excluded pay issue is Treatment of Workers. 